of high mountains, fully establish this fact. Observations of the upper clouds further indicate that when a cyclonic disturbance travels eastward in our latitudes, the passage of its centre is usually accompanied (or, more strictly, followed) only by a temporary backing and subsequent veering of the westerly upper-currents, showing that where we have circular isobars at the earth's surface, we should find in the region of the cirrus merely a loop or bend in the isobars for that altitude, could such isobars be drawn. Could we in short have a weather-chart confined to the region of cirrus, we should see in it, in lieu of a deep cyclone, a shallow "secondary" travelling round a portion of the great polar area of depression.

It is true that north-easterly winds may thus be subject to more retardation due to friction at their upper surface than south-westerly winds. But in a fluid like the atmosphere the whole effect of this retardation must be conceived as almost insignificant.

The question, then, that I would ask is this:-May not the fact that any given gradient for an east wind is wholly contributed by the strata of atmosphere near the earth's surface, while a similar gradient for a west wind is contributed by the whole mass of atmosphere overhead, be imagined, consistently with what we know of the mechanics of the atmospheric currents, to give a greater force of wind in the former than in the latter case, at the surface of the earth?

There is one other point to which I may be here permitted to call attention, though it relates to language alone. I have employed above, consistently with common usage, the expression "gradient for" a particular wind ; but this expression appears liable to the objection that it involves a hypothesis, and one which is moreover not in accordance with fact. "A gradient for a southwest wind" signifies a distribution of pressure in which isobars lie south-west and north-east, and in which the lowest pressure is in the north-west and the highest in the south-east. But it is only in the higher latitudes, and on a level surface such as the sea, that this distribution is actually accompanied by a south-west wind. In inland localities, even as far north as the latitudes of the British Isles, it is accompanied by a wind between south-south-west and south; in lower latitudes by a wind still more from the higher to the lower pressures, and finally at the equator such a distribution of pressure would be accompanied by a south-east wind. Further, the expression leads to the needless ignoring of the more local deflections of the winds produced by irregularities of the earth's surface. Would not the expression "north-westward" gradient, simply indicating that barometric pressure decreases most in a north-westward direction, be more correct and equally intelligible? Such a gradient would be one for winds between south-west and south in our northern latitudes, for winds between north-east and east in corresponding southern latitudes, and for winds from the intermediate points over intermediate portions of the globe. "North-westward," "northward," and "north-eastward," \&c., gradients, are moreover slightly shorter expressions than gradients "for south-west," "for west," "for north-west winds," \&c.

W. Clement Ley

\section{SCIENCE IN CHINA}

I.

THE Department for the Translation of Foreign Books at the Kiangnan Arsenal, Shanghai, which has for its object the translation and publication of books relating to the arts and sciences of the West, was established towards the close of the year 1869 , mainly through the instrumentality of Messrs. Hsii and Hwa, natives of Wuseih, and who at that time were on the staff of officials at the Kiangnan Arsenal. The causes which led to the comBy Mr. John Fryer, Chief Translator to the Chinese Arsenal. mencement of this important undertaking are, however, traceable to a much earlier date. In fact, to find a suitable starting-point for its history, it is necessary to go back to the earlier portion of the lives of these two Chinese gentlemen.

Wuseih is an important city on the borders of the $\mathrm{Ta}$ $\mathrm{Hu}$, or Great Lake, in the province of Kiangnan, and has long been noted for its industrial pursuits, as well as the energy and enterprise of its inhabitants, many of whom have emigrated to Japan at various times. It was in this busy place that a little coterie of intelligent scholars was formed, all deploring the hollow and unsatisfying nature of the ordinary routine of Chinese studies. They determined to push their investigations in a more useful and promising field by endeavouring to become acquainted with the great laws of nature, and to gather as much information as they possibly could respecting the various branches of science and art.

Without organising themselves into a society, these aspirants for intellectual light used to have occasional meetings of an informal kind for mutual improvement, each person explaining any new facts or ideas he had acquired. The works of the early Jesuit fathers on mathematics, astronomy, and kindred subjects were carefully read, as well as original native works. But at last, during a visit to Shanghai, they found a valuable prize in Dr. Hobson's translation of a treatise on Natural Philosophy, published at the Lordon Mission Hospital in Canton in the year I855. This book, though of a very elementary character, was like the dawn of a new era upon their minds, enabling them to leap at one bound across the two centuries that had elapsed since the Jesuit fathers commenced the task of the intellectual enlightenment of China, and bringing them face to face with the results of some of the great modern discoveries. Apparatus was extemporised at their homes to perform the various experiments described in its pages, and every new theory or law was put to the test as far as their limited means would permit. Frequent papers were written and circulated from one to another, while queries were continually started by individuals asking for more information on difficult subjects. A pile of such manuscripts accumulated in the house of Mr. Hsü, who, with his son, formed a sort of centre for this little oasis in the midst of a vast desert of ignorance and superstition. Unfortunately, however, these manuscripts were all destroyed when the Taiping rebels captured the city, and the little company were glad to escape with their lives to the neighbouring hills, among which they found a temporary refuge. Even in these trying circumstances they were able to turn their knowledge to good account in different ways so as to alleviate their own hardships as well as those of their fellow-sufferers.

In the third moon of the first year of Tung-che, or 1862 an Imperial edict called upon the Governor-General of the "Two Kiang" provinces to search throughout his jurisdiction for men of talent and ingenuity, and versed in the arts and sciences, who should assist in improving the condition of the Empire. H. E. Tsêng Kwo-fan accordingly selected six men, whose names were duly forwarded to Peking. Among the number were Messrs. Hsü and Hwa, whose reputation as scientists had by this time extended far beyond their native town. They were afterwards invited to an interview with the Governor-General at Anching, and were at once retained on his staff, with the view of their being able to study and perfect themselves in the more useful branches of the foreign arts, sciences, and manufactures.

At that time the rebels were in possession of Nanking, and the surrounding country was in a most unsettled state, so that little could be done in the direction of improvement or study. Mr. Hwa, however, was engaged with others in collecting and preparing such scientific books as China then possessed. This work was after- 
wards continued at Nanking, where, under the auspices of the Viceroy, an establishment was commenced for the publication of useful books. Many valuable works, such as Mr. Wylie's translation of Euclid, the Differential and Integral Calculus, Dr. Edkin's translation of Mechanics, and similar treatises, have already been republished there, and the establishment is still in existence.

While Mr. Hwa was engaged in this kind of labour, Mr. Hsii was called upon to perform a task of a very different kind. The Viceroy required him to build a steamboat, and reluctantly he consented to make the attempt. He first made a model of an engine from the somewhat rough illustrations in Dr. Hobson's work before referred to. This proving to be a success, he was encouraged to proceed with the more difficult task assigned him. By means of Chinese tools and materials, and such ideas as he contrived to get through looking carefully over a small steamer at Anching, he managed to prepare his designs, and commenced his work with no foreign assistance whatever. $\mathrm{He}$ met with a most determined opposition from local officials, but, assisted by his son and encouraged by the Viceroy, who took a lively interest in the proceedings, the work was at length completed; not, however, without at least one entire failure. The steamer, which was of twenty-five tons measurement, was able to make $255 \mathrm{li}$, or about 85 miles, in fourteen hours, and to do the return journey in less than eight hours at her trial trip on the Yang-tse in 1865 . The Marquis Tsêng, now ambassador to England, also took great interest in this little craft, giving her the highly classical name of Wang-kao or Yellow Swan, and making several trips in her on the Yang-tsze.

It will be readily granted that the experience gained under so many difficulties ought to have given Mr. Hsii and his son somewhat of an insight into foreign arts and sciences, and to have raised them far above the level of the best of their fellow-countrymen. Not contented, however, with the small stock of knowledge they felt they possessed, they made several visits to Shanghai, in some of which they were joined by $\mathrm{Mr}$. Hwa, with a view to making new mental acquisitions. During these visits they made the acquaintance of Mr. Li Shan-lan, the celebrated native mathematician, who was then translating with the Rev. J. Edkins and Mr. Wylie such works as Whewell's "Mechanics," Herschel's "Astronomy," Euclid, the Calculus, \&c., at the London Mission. On these occasions they added largely to their intellectual attainments. They also gained many new ideas from other well-known Sinologues, such as the Revs. Messrs. Muirhead and John, and Dr. Williamson, for whom they often express much respect.

At length deciding to settle in Shanghai for the convenience of carrying on their investigations and studies in the vicinity of foreigners, they obtained from $H$. E. Tsêng Kwo-fan a mandate attaching them to the staff of officials at the Kiangnan Arsenal, which had recently been commenced. Here they arrived in the beginning of the year 1867, and soon endeavoured, in connection with the Arsenal directors, Fung and Shen, to organise methods by which their long-cherished hopes might be realised and their thirst after knowledge satisfied. Their aspirations finally resolved themselves into a definite form, and led them to devise a plan for the translation and publication of a series of treatises on the various branches of Western learning that should bear some resemblance to the Encyclopadia Britannica, of which they had ordered a copy from England. In this manner they hoped not only to instruct themselves, but to diffuse the knowledge they had acquired with so much pains among their fellow-countrymen, and leave behind them a lasting name throughout the Empire. It was also imagined by them that such a series of treatises would prove especially useful as text-books in various educational establishments of a high order, which it was then hoped would soon be instituted in the different provinces.

This scheme was warmly taken up by the directors of the Arsenal, who easily obtained the permission of the Viceroy to begin to carry it out on a small scale by way of experiment. Various foreign gentlemen were applied to for their services, but without success, till at last a commencement was made by Mr. Fryer, who at that time was editing the Chinese newspaper published at the North China Herald Office in Shanghai. He was asked to purchase a collection of suitable European books, and to begin at once to translate a work on Practical Geometry with Mr. Hsü, jun. Subsequently Mr. A. Wylie's services were secured for a treatise on the Steam Engine, with Mr. Hsü, sen., while Dr. Macgowan undertook the translation of a work on Geology with $\mathrm{Mr}$. Hwa. These three books, which formed the beginning of this large undertaking, were translated at the residences of the Europeans above named. It soon became manifest, however, that it would be impossible to carry on the work successfully except at the Kiangnan Arsenal, where the books were to be printed and published, and which is distant about four miles from the foreign settlement. Here Mr. Fryer was pressed to give his whole time and attention to translation, and in June of 1868 commenced his labours in a building which was set apart for that purpose. The earliest publications gave such satisfaction to the Viceroy at Nanking that he ordered the operations of the translation department to be extended ; the immediate result of which was the addition of Mr. (now Dr.) Kreyer to the regular staff. Subsequently when the Government school for interpreters had been removed from inside the Chinese city to the arsenal, Mr. (now Dr.) Allen's services were re-engaged to conduct it, and he was further asked to give a portion of his time to the work of translation. Dr. Kreyer, after rendering effective service as a translator for some time, left his post for that of interpreter to the Taotai of Shanghai, much to the loss of the department. The vacancy was afterwards filled by Dr. Suvoong, a Chinese graduate of the United States, who has begun to enrich the collection of books by translations of medical and other works, for which task his long residence and studies in America have well qualified him.

The number of the native members of the staff has been subject to frequent changes. At present there are five Chinese gentlemen who are engaged either in writing the translations or in preparing the various books for publication. Among this number Mr. Hsit, sen., is the only one who has remained constantly at his post from the commencement, and whose desire for knowledge does not yet appear to abate, although he is now well advanced in years. Others have worked for longer or shorter periods, and then have either grown tired of such monotonous labour, or have accepted official appointments that were offered to them. This continual changing has not been without injurious effects in some cases. Either important books have been left half finished, no one liking to take up another's work, or if finished the manuscripts have been taken away or passed from one to another, so that after the lapse of a year or two they cannot be found.

Among the officials who have left the work for higher appointments may be mentioned $\mathrm{H}$. E. Li Fung-pao, the present Minister to Berlin; Mr. $\mathrm{H}_{s} \ddot{u}$, jun., who has just started to join him as secretary, and who was lately Director of the Shantung Arsenal; Mr. Hwa, who has been Director of the Tientsin Powder Works, and now is Resident Curator of the Chinese Polytechnic Institution; Mr. Wang, who is a director of the Tientsin Arsenal; and Mr. Hwang, an attaché of the Chinese Legation in London. The names of several other gentlemen in important positions might also be added, all of whom were at one time or another on the staff, and manifestly derived 
benefit from carrying on work which brought them into daily contact with Europeans. Viewed, therefore, merely in the light of an educational establishment, this department has been of much benefit to the Government by supplying so many intelligent and well-informed officials, al more or less imbued with favourable notions respecting foreigners and a desire to see foreign intercourse extended.

The history of Mr. Ka Pu-wei, who has for several years worked in connection with this department, is almost as remarkable as that of Messrs. Hsü and Hwa. From his childhood he had a strong leaning to mathematical studies; but not being in independent circumstances, he was obliged to support himself by keeping a rice-shop inside the city of Shanghai. Here he prosecuted his studies with such success that he was able to calculate eclipses and to prepare an almanac giving particulars respecting the movements of the heavenly bodies, which he ventured to publish. The Government alone having the authority to publish almanacs, and the country being at the time unsettled by the Taiping rebellion, he was charged with having designs against the Imperial throne, and cast into prison. He narrowly escaped with his life, but suffered imprisonment for above a year, till his friends could procure his release. $\mathrm{He}$ is now chiefly engaged in compiling and publishing a nautical almanac, calculated for the longitude of Shanghai instead of Peking or Greenwich, and in preparing various books of mathematical tables, for all of which his past studies have been an excellent means of preparation.

Equally interesting is the history of $\mathrm{Mr}$. Li Shan-lan, who was for a short time connected with the Translation Department before his removal to Peking, as Professor of Mathematics in the University of that city. He is a native of the Province of Chekiang, and from his earliest years manifested a remarkable genius for the science of numbers. In the year 1845 he began to publish original treatises embracing different problems in the higher mathematics. On one occasion when at Shanghai he went to a chapel where Dr. Medhurst was preaching to a Chinese congregation, and showed him one of these works. This resulted in his being engaged in the London Mission, where Mr. Wylie took him in hand and translated with him several mathematical works of the highest order, as well as Herschel's "Outlines of Astronomy." With Dr. Edkins he translated Whewell's "Mechanics." Nothing in the way of science seemed to come amiss to him. Eventually he commenced Newton's "Principia" with Mr. Wylie, of which he only translated a small portion of the first book. The remainder of the first book he finished at the Kiangnan Arsenal with Mr. Fryer during the few months of his connection with the Translation Department. $\mathrm{He}$ seemed to enter into the most intricate of its problems with the greatest zest and enthusiasm, and often expressed his intense admiration for Newton's genius. His skill in solving the most difficult mathematical questions that could be given him was truly remarkable. Of course there are not many men of his calibre to be found in China; but still no doubt others will be brought to light through the impulse which foreign intercourse is bringing to bear upon the stagnant minds of this long-isolated nation. Now and then a lesser light than $\mathrm{Li}$ Shan-lan appears among the various visitors at the Arsenal, and it is reported that $\mathrm{Ku}$ Shang-chib, a native of Chiu-shan, is in advance of him; but this needs confirmation.

The establishment where the books are printed in the old-fashioned way from wooden blocks was first merely a small room, but has now grown into a separate range of buildings, and employs upwards of thirty hands as block-cutters, printers, bookbinders, \&c., and is superintended by an under-official. Another under-official has charge of the books when printed, and is responsible for the money derived from their sale. About half-a-dozen copyists complete the personnel of the department.

The library of foreign books consists now of several hundred volumes, and forms probably the best collection of the kind in China. It is contemplated to make extensive additions shortly of recent important publications.

It may be mentioned that, as a mark of Imperial favour, various honorary degrees of rank have been conferred upon the native and foreign members of the Translation Department, in acknowledgment of the value of their services. Mr. Fryer, Dr. Kreyer, and Dr. Allen received diplomas entitling them to the third, fourth, and fifth degrees of civil rank respectively.

On various occasions some of the highest officials in the Empire have sent requests for books to be translated, bearing on subjects in which they took particular interest. Notably this has been the case with H. E. Li Hung-chang. Among the high dignitaries who have expressed their satisfaction at the results attained by this department, it may be mentioned that on one occasion, when staying at the Arsenal, H. E. Ting Jih-chang expressed himself in strong language as to the importance which he attached to the translation of books, compared with the work carried on in other departments. The Marquis Tsêng, who resided for a few days at the Arsenal in 1877, and has from the first been in favour of the undertaking, gave Mr. Fryer a Chinese fan, on which he had written by way of compliment a verse of Chinese poetry of his own composition, and which may be freely translated as follows :-

" Nine years have elapsed since our last conversation;

But your translations have been forwarded to me from time to time.

May your fame surpass that of Verbiest and Schaal,

As the electric light exceeds the spark of the glowworm." ( $T o$ be continued.)

\section{THE GREAT VIENNA TELESCOPE}

$T H E$ political and social disturbances in Ireland have of late somewhat diverted attention from the literary and scientific work done in that country. Such work has nevertheless proceeded on its quiet way despite land agitation, failure of crops, or even commercial distress ; and Ireland is to be congratulated on the completion of the fine 27 -inch refracting telescope, designed and con-

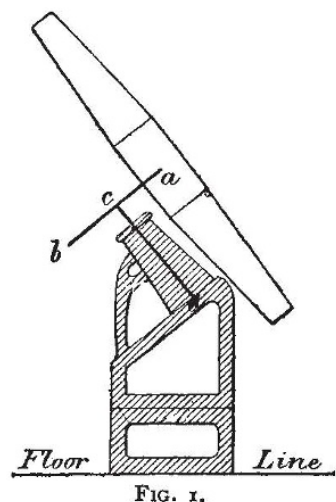

structed by Mr. Howard Grubb of Dublin for the Imperial and Royal Observatory of Vienna.

This telescope is the largest equatorial refractor at present in existence. In the year 1873 Director Littrow, of the National Observatory of Vienna, induced the then Austrian Minister of Public Construction (R. von Stromayer) to consent to the removal of the Observatory from the old site in the Vienna University grounds to a more favourable site, consisting of a level piece of ground 